\title{
NEGOCJOWANIE ZNACZENIA OBJAWIEŃ MARYJNYCH NA ZAKARPACIU, CZYLI BADANIA POLITYKI RELIGII W PERSPEKTYWIE KOGNITYWISTYCZNEJ WEDŁUG MONOGRAFII AGNIESZKI HALEMBY
}

Książka Agnieszki Halemby Negotiating Marian Apparitions. The Politics of Religion in Transcarpathian Ukraine (2015), którą tu zamierzam przedstawić, jest dla mnie ważna, ponieważ podzielam z autorką potrzebę refleksji nad sposobami konstruowania perspektywy porównawczej w antropologii. Zanik komparatystyki w dobie postmodernizmu, jednoczesny z upadkiem metanarracji, doprowadził do fragmentacji badań, tym groźniejszej, że towarzyszącej procesom różnicowania się kultury. Jak pisał Jean Baudrillard, wszędzie dziś piętrzymy różnice, co odtwarza i potęguje atmosferę konfliktu społecznego. Niemodne jeszcze wczoraj pytanie o uniwersalia staje się coraz bardziej palące.

Monografia o negocjowaniu znaczenia objawień maryjnych w kontekście ścierania się dyskursów religijnych na ukraińskim Zakarpaciu powstała jako efekt badań, które autorka prowadziła początkowo w ramach zbiorowego projektu Centre of History and Culture of East/Central Europe na Uniwersytecie w Lipsku. W badaniach przyjęto trzy toposy jako osie umożliwiające porównanie konstrukcji religijnej i narodowej tożsamości mieszkańców Europy Środkowo-Wschodniej: kult maryjny, Cyrillo-Methodiana i ideę chrześcijańskiego przedmurza. W stopniowo

\footnotetext{
${ }^{1}$ Projekt ten, zatytułowany „Religious Tradition, Communism, and Cultural Reevaluation: Transnationalism in post-1989 East European Cultures of Remembrance", kierowany przez prof. Stefana Troebsta, realizowany był w Karpatach, uznanych za pogranicze Wschodu i Zachodu, Europy i Azji (Halemba 2015: 27).
} 
wypracowywanym własnym projekcie Agnieszka Halemba skoncentrowała się na pierwszym z „toposów”, czyli kulcie maryjnym, obierając jako punkt wyjścia dla swojego kwestionariusza badawczego objawienia zapoczątkowane w 2002 r. w Dżubliku (ukr. Джублик), w obwodzie i dekanacie irszawskim, w greckokatolickiej eparchii mukaczewskiej Kościoła katolickiego obrządku bizantyjsko-rusińskiego. Odrębna historia i status tej eparchii, niezależnej od Kościoła katolickiego obrządku bizantyjsko-ukraińskiego, wyraża się w bezpośrednim podporządkowaniu Stolicy Apostolskiej, co odzwierciedla specyfikę tożsamości jej wiernych wobec grekokatolików Zachodniej Ukrainy, a także tendencje separatystyczne Zakarpacia.

Wybór Dżublika, miejsca niedawnego objawienia maryjnego (w sierpniu 2002 r.), umożliwił Halembie kilkuletnią obserwację dynamiki wydarzeń i zmian, dokonywanych w kolejnych przekazach z nim związanych oraz w jego ocenie ze strony duchownych i Kościoła. Według małych wizjonerek z wioski Niżne Bołotne, Marianki i Olenki, które w momencie objawienia nad źródełkiem miały dziewięć i dziesięć lat, Dziewica Maryja przyszła, aby pomóc odbudować autorytet księży, zjednoczyć ludzi i Kościół. Po objawieniach maryjnych miały jednak miejsce kolejne, o odmiennym charakterze: pojawił się św. Józef (w Dżubliku kult Św. Rodziny z czasem zdominował maryjny), słońce tańczyło, krzyż krwawił.

Autorka nie ograniczyła badań do wiosek położonych w sąsiedztwie miejsca objawień, które stopniowo zmieniało się w popularne centrum pielgrzymkowe. Celem nie była bowiem obserwacja społeczności lokalnej (ten rodzaj stacjonarnych badań we współczesnym świecie staje się coraz bardziej problematyczny), lecz sieci relacji i praktyk społecznych organizacji religijnej. Badaczka uczestniczyła więc w wydarzeniach organizowanych przez władze kościelne, podróżowała do sąsiednich obwodów i wzięła udział w pielgrzymkach ze Lwowa do Dżublika oraz parafialnych - z Dżublika do Medjugorie i Lourdes. Pracowała w miejskim archiwum w Użhorodzie oraz uzyskała dostęp do niektórych dokumentów mukaczewskiej eparchii greckokatolickiej, a także prywatnych archiwów historycznych, w tym do dokumentów ks. Iwana Margitycza, pierwszego biskupa pomocniczego w Użhorodzie po reaktywacji Kościoła greckokatolickiego w Ukrainie. Te różnorodne praktyki badawcze złożyły się na przemyślaną metodykę pracy, która umożliwiła pozyskanie bogatych i zróżnicowanych materiałów źródłowych.

Większość rozmów autorka prowadziła w środowiskach greckokatolickich i prawosławnych duchownych, a może czytelnik odnosi tylko takie wrażenie, bo praca 
ze zrozumiałych względów nie zawiera spisu rozmówców, ani nawet spisu rozmów (co już trochę mniej oczywiste). W każdym razie cytowane są głównie fragmenty wywiadów z duchownymi, zaś w przypadku laikatu dominują opisy obserwowanych przez badaczkę praktyk i zachowań. Halemba pisze, że przeprowadziła wywiady z wszystkimi greckokatolickimi księżmi pracującymi w dekanacie irszawskim oraz z członkami rad kościelnych i wiernymi parafii greckokatolickich. Mieszkała również w domach świeckich parafian, uczestnicząc w ich praktykach religijnych, np. $\mathrm{w}$ tradycyjnych domowych zgromadzeniach, podczas których śpiewają psalmy, zazwyczaj w intencji za zmarłych.

Koncentracja na grupie wykształconych rozmówców, reprezentujących stosunkowo wąskie środowisko, zyskuje coraz większą popularność wśród antropologów, odkąd zaczęli badać dyskursy. Dzięki temu etnograf w pewnym sensie ułatwia sobie pracę, bowiem uzyskuje informacje już wstępnie uporządkowane w wymiarze społecznym, zazwyczaj też kulturowym, co bywa szczególnie ważne w obliczu współczesnych procesów indywidualizacji i zróżnicowania kulturowego. W przypadku duchownych zyskuje też rozmówców sprawnie formułujących przekazy werbalne. Greckokatoliccy duchowni na Zakarpaciu stamtąd też pochodzą, chociaż wielu z nich studiowało poza Ukrainą; są zatem kompetentnymi komentatorami lokalnego życia religijnego. Taki wybór rozmówców odpowiadał ponadto celowi autorki, czyli studiom z zakresu tytułowej polityki religii.

Monografia może wywołać w czytelniku wrażenie pewnej niekonsekwencji, spowodowanej konfrontacją między krytycznym wstępem, wprowadzającym nowe założenia teoretyczne, a klasyczną antropologiczną narracją głównego tekstu monografii. Halemba deklaruje bowiem kognitywistyczne podejście do religii, co oznacza zarówno zaprzeczenie jej autonomii jako możliwej do wydzielenia sfery ludzkiego życia („postrzeganie i definiowanie religii jako zunifikowanej całości jest daremne”2), jak i samego pojęcia doświadczenia religijnego. Autorka powołuje się tu na przekonanie kognitywistów, że nie istnieje doświadczenie religijne sui generis, czemu towarzyszy całkowite odrzucenie prac klasyków religioznawstwa, takich jak RudolfOtto, Gerardus

\footnotetext{
${ }^{2}$ Podobne było stanowisko C. Lévi-Straussa, który także przyjmował perspektywę poznawczą, uznając „myśl nieoswojoną” za przedmiot swojej uniwersalistycznej antropologii, chociaż był zdecydowanie krytyczny wobec podporządkowania badań ludzkiej kultury socjobiologii. (W kwestii religii jako przedmiotu badań por. końcowy fragment Totemizmu; krytykę koncepcji Edwarda Wilsona zawiera np. esej Etnolog wobec kondycji ludzkiej z 1979 r. [Lévi-Strauss 1993: 55-72]).
} 
van der Leeuw czy Mircea Eliade, którzy podejmowali próby charakterystyki cech specyficznie religijnych doświadczeń czy też istoty religii.

Ostatecznie jednak klarowny projekt teoretyczny pracy ${ }^{3}$, chociaż wpisuje się we wspomniane deklaracje, nie prowadzi czytelnika monografii ku tajnikom tzw. kognitywizmu. Religia jako aspekt ludzkiego życia ma być bowiem rozpoznawana na trzy sposoby: jako doświadczenie, instytucja społeczna i organizacja, których zmienne relacje pozwalają uchwycić cykliczną dynamikę zjawisk religijnych od sekt do ich „kostnienia” w kościoły, od bezpośredniego doświadczenia po zbiurokratyzowaną organizację. Pojęcie religii, używane jako termin emiczny wielu społeczności, pozostaje zatem narzędziem heurystycznym nauk społecznych. Antropologia zaś dysponuje narzędziami, które umożliwiają śledzenie w małej skali („z perspektywy robaka") interakcji, zachodzących między trzema wspomnianymi poziomami zjawisk. Wybrane przez Halembę objawienie maryjne okazało się dobrym punktem wyjścia takich badań,

ponieważ jest oparte (bądź deklaruje się, że jest) na religijnych doświadczeniach jednostek, a następnie wywołuje podobne doświadczenia u innych osób; współgrają one z instytucjonalnymi wzorami i/lub stanowią przedmiot często bardzo szybkiej instytucjonalizacji; są przedmiotem zainteresowania organizacji religijnych, ponieważ zazwyczaj mają miejsce w obrębie Kościoła katolickiego (Halemba 2015: 90),

czyli scentralizowanej i hierarchicznej organizacji religijnej. Te trzy analityczne pojęcia Halemba uznaje zarazem jako szczególnie odpowiednie dla studiów nad religią $\mathrm{w}$ regionach postsocjalistycznych.

Odmawiając definiowania religii, autorka podąża do pewnego stopnia śladem Maxa Webera, który deklarował, że nie interesuje go istota religii, a za swoje zadanie przyjmuje „raczej badanie warunków i skutków określonego typu społecznego zachowania" (cyt. za: Piwowarski 1996: 9) z perspektywy ich racjonalności. Również wprowadzając trzy wspomniane pojęcia analityczne, Halemba kontynuuje w zasadzie zainteresowania klasyków antropologii (prace z zakresu antropologii religii przyjmujące perspektywę funkcjonalną eksplorowały zazwyczaj trójaspektowy model: doktryna/kult/organizacja, który umożliwiał badania porównawcze). Posługuje się też klasyczną etnograficzną metodą badań dostosowaną, jak wspomniałam, do współczesnej glokalizacji, która odmienia sens „lokalności”.

\footnotetext{
${ }^{3}$ O modelu tym zob. też Halemba 2014.
} 
Struktura samej rozprawy ma również charakter, rzec można, klasyczny. Inicjującym i przewodnim wątkiem jest doświadczenie, czyli seria objawień zapoczątkowanych w 2002 r., których przesłanie przekazały dziewczynki z wioski Niżne Bołotne. Toteż po wprowadzeniu, w którym jest mowa o założeniach teoretycznych projektu i praktyce badawczej oraz analizie objawienia w Dżubliku w kontekście wzorów nowoczesnych objawień maryjnych (to znaczy poczynając od Lourdes, 1858), kolejne rozdziały dotyczą tematów inspirowanych dżublickim przesłaniem. Jest to więc wezwanie do jedności ludzi i Kościoła - punkt wyjścia dla studium problemów tożsamości i organizacji Kościoła obrządku bizantyńsko-rusińskiego na Zakarpaciu - oraz wezwanie do odbudowy autorytetu księży po długim okresie destrukcji organizacji kościelnych w ZSRR. W tym kontekście odnajdujemy również interesujący obraz działalności podpolnych kapłanów i jej współczesnych konsekwencji w kontekście dyskusji z weberowską teorią charyzmy i biurokracji. Autorka konstruuje także typologię podejmowanych przez księży współczesnych strategii budowania autorytetu. Kolejny rozdział - „Wołanie o jedność i zarządzanie heterogenicznymi praktykami" - zbudowany jest wokół przeciwstawienia tradycyjnego życia religijnego, toczącego się w ramach parafii, praktykom sieci, które pozwalają laikatowi tworzyć interaktywne wspólnoty ponad granicami kościelnej organizacji i zaspokajać osobiste potrzeby wiernych. W konkluzji objawienia maryjne uzyskują metaforyczne określenie „miejsc przemiany”. W postsocjalistycznej Ukrainie, jak dowodzi Halemba, organizacje religijne próbują kierować zmianami życia religijnego lokalnych społeczności w taki sposób, aby dostosować doświadczenia i instytucje wiernych do swoich form organizacyjnych. Chociaż pisząc o organizacjach religijnych autorka stosuje zazwyczaj liczbę mnogą, wnioski dotyczą głównie Kościoła katolickiego.

„Klasyka” modelu teoretycznego okazuje się jednak przy dokładniejszej lekturze pozorna wobec meta-celu, który ostatecznie przyświecał autorce i wpisuje się w deklarowane we wstępie założenia. Celem tym jest bowiem próba zbudowania zarzuconej przez antropologów zajmujących się religią uniwersalnej perspektywy, która umożliwi porównanie praktyk Telengitów i zakarpackich grekokatolików, a także doświadczeń, instytucji i organizacji religijnych innych społeczności. Świadczą o tym podejmowane kilkakrotnie w monografii próby tego rodzaju zestawień, z pewnością inspirujących, jakby autorka postanowiła ograniczyć się - na razie - do najbardziej dla niej użytecznych przypadków, pozostawiając na przyszłość peł- 
niejszą realizację tego odważnego zadania. Ten meta-teoretyczny kontekst oznacza zarazem próbę wy pracowania relacji pomiędzy uniwersalistyczny mi zainteresowaniami kognitywistów a praktyką etnograficzną z jej badaniami w mikroskali. Jeśli się to uwzględni, to wszystkie trzy wspomniane terminy (doświadczenie, instytucje i organizacje) nabierają oczywiście nowego znaczenia. Już nie racjonalny charakter wierzeń i praktyk religijnych (jak u Webera czy Lévi-Straussa), a nawet nie ich funkcje społeczne, ale ich znaczenie w kontekście ewolucji biologicznej ma stanowić ów meta-poziom, z którego w przyszłości będzie można dokonywać porównań. Oznacza to powrót do antropologicznego holizmu wielkich systemów, z konieczności transdyscyplinarnych.

„Religia” byłaby zatem zjawiskiem naturalnym (jak przekonują Daniel Denett czy Richard Dawkins), formą kolektywnej pamięci, analizowaną w kategoriach psychologii ewolucyjnej (jak to czyni np. Pascal Boyer). Kognitywiści chcą rozpoznawać wzory ludzkiej myśli i zachowania, które mogą być uznane jako religijne, a następnie próbują wyjaśnić, dlaczego te wzory powracają w różnych kulturach (Justin Barrett). Interesują ich „ogólne, prawdopodobnie uniwersalne mechanizmy poznawcze", które najwyraźniej umożliwiły pojawianie się doświadczeń, zachowań i pojęć, jakie w specyficznych okolicznościach mogą być uznane za religijne. Halemba zwraca jednak uwagę, że w bardzo ograniczonym stopniu poddają oni refleksji problem, dlaczego pewne doświadczenia są uznawane za religijne w specyficznych społecznych kontekstach. To właśnie uznaje za zadanie dla antropologa, który dysponuje odpowiednimi narzędziami, aby uzyskać dane umożliwiające odpowiedź na pytanie o zasady takiej klasyfikacji.

Scenariusz pomocny dla obserwacji procesu przypisywania religijnego charakteru określonemu doświadczeniu autorka odnalazła w kognitywistycznej pracy Ann Taves (2009). Według Halemby zaproponowana w niej interpretacja (która z kolei odwołuje się do Doświadczeń religijnych Williama Jamesa) ,jest wprost Durkheimowska”: „religijny” jest bowiem przede wszystkim fenomen uznany za „specjalny”, „oddzielony” $i$ „wyjątkowy”. „Proste przypisanie” (simple ascription), według którego pewne wydarzenie zostaje wydzielone jako „wyjątkowe”, powinno być analitycznie oddzielone od „złożonego opisu”, w którym owe „proste przypisania” zostają wcielone do złożonych formacji, jak te nazywane „duchowością” albo „religią”. Halemba zakłada, że proces przypisywania „wyjątkowości” wydarzeniu, fenomenowi czy procesowi ma charakter społeczny. Te 
„specjalne rzeczy” najczęściej są oddzielane dlatego, że są uważane za idealne (wydają się doskonałe lub kompletne) albo - za anomalne (dziwne i niecodzienne).

„Religijność" pojawia się na następnym poziomie analizy, kiedy bada się, jak „specjalne rzeczy” są społecznie rozpoznawane i jak są budowane „specjalne ścieżki”, czyli zestawy praktyk - „rytualne wzory”, które jednostki bądź grupy postrzegają jako efektywne w osiąganiu celów związanych ze „specjalnymi rzeczami”. Ten proces Halemba nazywa instytucjonalizacją religii. Instytucjonalizacja to zatem proces reprodukcji, powtarzania i stabilizacji akcji społecznej, pisze Halemba, odwołując się do teorii Petera Bergera i Thomasa Luckmanna.

Kluczowe dla pracy jest rozróżnienie pomiędzy religijną instytucją a religijną organizacją, czyli „odpowiednie rozpoznanie poziomu danego wzoru społecznego zachowania jako oddzielonego on innych aspektów życia". Zgadzam się z autorką, że przyczyniło się to do większej precyzji opisu życia religijnego, chociaż z drugiej strony umożliwiło jej, moim zdaniem, zbyt radykalne wypreparowanie aspektu organizacyjnego (do tej sprawy powrócę w zakończeniu). Towarzyszą tym pojęciom ich odpowiedniki procesualne, czyli instytucjonalizacja i to, co autorka nazywa „organizacyjnym włączeniem” (organizational embracement). Ten zestaw pojęciowy umożliwił, obok udanej próby diachronicznego uchwycenia życia religijnego, radykalne unikanie esencjalizacji.

Instytucje i organizacje, przynajmniej w sferze religijnej, są dla autorki złożonymi wzorami ludzkiego zachowania, obszarami negocjacji i redefiniowania ról i celów. Jednak organizacja, w przeciwieństwie do instytucji, jest jednocześnie wewnętrznie i zewnętrznie wyraźnie zobiektywizowana. Zarówno instytucje, jak i organizacje regulują społeczne doświadczenia i działania. Jednak podczas gdy role instytucjonalne są w dużej mierze ukryte i muszą zostać wykrystalizowane przez badacza z ludzkich działań, role organizacyjne są wyraźnie zdefiniowane i często nawet skodyfikowane na piśmie. Instytucje społeczne to „stosunkowo stabilne (...) mechanizmy, regulujące ludzkie zachowania”, np. małżeństwo, przyjaźń, czary czy praktyki szamańskie. Są one jednak „najczęściej wyraźnie oddzielone od biegu życia codziennego i nawzajem od siebie nie przez ludzi, którzy strukturyzują swoje życie zgodnie z wzorcami ich mechanizmów, ale przez zewnętrznych obserwatorów z badaczami społecznymi na czele, którzy próbują opisać regularności ludzkich zachowań" - zauważa autorka $\mathrm{i}$ jest to z pewnością refleksja mocno ugruntowana w praktyce etnograficznej. 
Organizacje są natomiast według autorki (za Davidem N. Gellnerem i Ericem Hirschem) mechanizmami, „które są wyraźnie rozpoznawalne dla zaangażowanych podmiotów i w których obrębie oraz poprzez które określone normy akcji są jasno i jawnie określone i mogą być wdrożone w praktyce". Są one postrzegane jako sprawcy (agents). Chociaż dla antropologa

[O]rganizacje są arenami intensywnego różnicowania, walk, tworzenia sieci, zawiązywania porozumień itd., lokalnie są postrzegane tak, jakby były aktorami - uniwersytet, kościół, szkoła - są opisywane jakby formułowały opinie, wydawały dekrety, zatrudniały i zwalniały, angażując się w sprawy publiczne itd. Co więcej, organizacje nie są obiektywizowane najpierw przez badaczy, ale przez ludzi angażujących się w ich operacje (Halemba 2015: 10).

Role organizacyjne mogą być podważane, kwestionowane bądź ignorowane przez różnych aktorów - w ten sposób instytucje społeczne wchodzą w interakcje z organizacjami i rzucają im wyzwanie. (Dzieje się tak np. wówczas, gdy wierni podejmują z księdzem - przedstawicielem organizacji - dyskusję na temat formy rytuału). Organizacje mogą też wytwarzać instytucje. Według Halemby procesy interakcji pomiędzy religijnymi instytucjami a religijnymi organizacjami "generują niektóre z najważniejszych i najbardziej płodnych pytań, które dotyczą tego, w jaki sposób religia jest obecna w ludzkim życiu" (Halemba 2015: 5). To właśnie te interakcje stanowią główny przedmiot jej zainteresowania, w mniejszym zaś stopniu same doświadczenia.

Jeśli pamięta się, że instytucja to pojęcie analityczne, a nie próba zdefiniowania zjawisk społecznych w sposób ontologiczny - pisze Halemba - to możemy z niego efektywnie korzystać w analizie. W studiach nad religią jej instytucjonalizację i rozwój religijnych instytucji należy odnosić do społecznie ustanowionych sposobów postępowania ze „specjalnymi rzeczami” lub, zgodnie z terminologią Taves, do budowania „specjalnych ścieżek”.

Co istotne - zwraca uwagę Autorka - na tym poziomie aktywność religijna nie wymaga, aby każdy doświadczał „specjalnych rzeczy” - ludzie mogą doświadczać ich zastępczo, poprzez podążanie „specjalnymi ścieżkami”. To jest poziom, na którym dotąd lokowano większość antropologicznych studiów nad religią - koncentrują się one na społecznie rozpowszechnionych i wprowadzonych w życie sposobach rozumienia "specjalnych rzeczy", które mogą być, pod pewnymi warunkami, nazywane religią, chociaż nie są lokalnie rozumiane jako tworzące wyraźnie wyodrębnione obszary życia (Halemba 2015: 8-9). 
Jak widać, teoretyczny projekt pracy został szczegółowo opracowany z zaprogramowaną perspektywą, otwartą na przyszłe studia kognitywne dzięki wprowadzeniu elementów teorii organizacji, co umożliwia porządkowanie konkretnych efektów badań etnograficznych na wysoce abstrakcyjnym poziomie dyskursu. Przejdźmy zatem do podsumowania efektów realizacji tego ambitnego projektu. Praca jest tak wielowątkowa, że z konieczności skupię się na kilku wybranych aspektach, zaczynając od interpretacji doświadczeń, czyli tytułowego „negocjowania” objawień maryjnych. Następnie omówię przedstawioną przez autorkę charakterystykę postaw duchownych i laikatu, negocjujących owo znaczenie. Oba te wątki są ze sobą splecione i posłużyły do skonstruowania dość radykalnych wniosków dotyczących Kościoła katolickiego. Dodam też drobny komentarz do dyskusji, jaką Halemba prowadzi w ostatnich rozdziałach pracy z tezą Vlada Naumescu o zachodnioukraińskim prawosławnym imaginarium (Orthodox imaginary), które według niego podzielają wyznawcy prawosławia i katolicyzmu obrządków wschodnich. Pominę natomiast ważny wątek znaczenia objawień dla polityki narodowościowej, ponieważ jest on z mojego punktu widzenia najmniej dyskusyjny.

Halemba dowodzi, że bezpośrednie interwencje tego, co uznawane za boskie (divi$n e)$, to czas próby dla organizacji religijnej. W tym kontekście objawienia w Dżubliku traktuje jako głos w toczącej się na Zakarpaciu dyskusji na temat roli organizacji religijnych w projektach narodowych, stosunków między religijnymi organizacjami, laikatem i jego wspólnotami, a także na temat sposobów „legalnej” realizacji życia religijnego wiernych. W trakcie objawień, jak opowiadają wizjonerzy i świadkowie, Maryja przemawia, komentując explicite problemy lokalne i globalne. Głos transcendencji nie tylko więc potwierdza swą obecność i moc, ale bezpośrednio doradza, w jaki sposób ludzie powinni żyć.

Objawienia w Dżubliku to zatem:

przykład oczekiwanej boskiej interwencji w sytuacji, kiedy ludzkie dyskusje i konflikty utknęły w martwym punkcie. Odwołanie się do świętej postaci przenosi dyskusję na nowy poziom: nie toczy się już między lokalnym odgałęzieniem religijnej organizacji, legitymizowanej poprzez swoje ulokowanie w globalnych hierarchicznych strukturach, a grupą ludzi, którzy nie zgadzają się z jej pozycją, tworząc swoje własne religijne instytucje i negocjując poziom ich "organizacyjnego włączania”.

Dyskusja - pisze Halemba - toczy się teraz między organizacją a samą transcendentną mocą, dostępną poprzez bezpośrednie doświadczenia uważane za religijne. 
W trakcie tego procesu niektóre $\mathbf{z}$ doświadczeń zostają zdefiniowane jako religijne, podczas gdy inne - odrzucone jako niewłaściwe, błędne lub, jeśli uznane za nadnaturalne, pochodzenia raczej szatańskiego niż boskiego. Te bezpośrednie interwencje $\mathrm{i}$ ich instytucjonalizacje są mocnymi argumentami w dyskusji z organizacją religijną i w jej obrębie (Halemba 2015: 268).

Efektem praktyk dyskursywnych, rozwijanych wokół objawienia, twierdzi Halemba, (odwołując się do Edwarda Berrymana, który studiował przypadek pewnego kanadyjskiego wizjonera), jest utożsamienie wizji ze świętą postacią, co powoduje, że odrzucenie wizji może być interpretowane jako odrzucenie samej świętej postaci. To odpowiada stanowisku wielu świeckich rozmówców Halemby: jest im trudno powiedzieć, że nie wierzą, jakoby dżublickie przesłanie przekazane wizjonerkom pochodziło rzeczywiście od Maryi, nawet jeśli dostrzegają wiele sprzecznych lub niepokojących cech tych objawień. „To tak jakby odrzucenie przesłania było równoznaczne z odrzuceniem samej Dziewicy Maryi, nawet jeśli Kościół nie wymaga, aby jego wierni okazywali nabożeństwo, czy nawet wierzyli w objawienia potwierdzone przez Kościół” (Halemba 2015: 273).

Halemba dostrzega uderzającą różnicę między postawami duchownych i laikatu wobec dżublickiego eksperymentu: tylko dla kleru istnieje wyraźny podział między tym, co dotyczy prawdziwości objawień, a oceną znaczenia Dżublika dla religijnej pobożności oraz jako miejsca kultu i pielgrzymek. Dla laikatu te dwie kwestie i oceny wydają się zespolone - jeśli objawienia rzeczywiście miały miejsce, to oznacza, że życie religijne powinno się tam rozwijać i w końcu przynosić zbawienne efekty. Jeśli zaś objawienia nie miały miejsca, modlitwy w Dżubliku nie mogą być dobroczynne. Zarówno dla wizjonerów, jak i pielgrzymów, podstawowe znaczenie ma zatem samo doświadczenie, a konflikty wokół miejsca objawień nie mogą go unieważnić. Pielgrzymi mogą być uznani za „drugą kohortę wizjonerów”; to ich własne bezpośrednie doświadczenie niezwykłości miejsca jest ważne: cud słońca, piękny zapach niewiadomego pochodzenia, znaki dostrzegane w chmurach, światła w lasach, uzdrowienia i nawrócenia, interakcje z wizjonerką.

Natomiast duchowni rozmówcy wyraźnie odróżniają różnicę między fałszem rozumianym jako oszustwo (false as fake), a fałszem rozumianym jako błąd (incorrect), zauważa Halemba. Chociaż wielu z nich uwierzyło, że Maryja faktycznie jest w specjalny sposób obecna w Dżubliku, to uznają zarazem, że to miejsce nie może dać zbawiennych rezultatów wskutek sposobu, w jaki jest zarządzane. Inni sądzą, że zdarzenia mogły zostać zmyślone, a mimo to miejsce przynosi korzyści życiu 
religijnemu. Jednak, jak twierdzi Halemba, księża w ogólności, włączając członków komisji kościelnej specjalnie powołanej dla oceny Dżublika, nie są zainteresowani ustaleniem, czy faktycznie Maryja się tam ukazała, czy nie. To, co uznają za istotne, to jakie owoce przyniesie objawienie, czyli jego efekty dla wiary wiernych oraz pozycji Kościoła jako organizacji.

Jednak ojciec Atanazy, były bazylianin, aktualny gospodarz i zarządca świętego miejsca, pytany o przyczyny sprzeciwu wobec decyzji biskupa, aby pozostawił Dżublik i powrócił do swojego klasztoru, prezentuje odmienną postawę. Uznaje, że posłuszeństwo należy się przede wszystkim Bogu i jego wysłannikom, nawet w przypadku sprzeciwu zwierzchnika. W ten sposób tworzy według Halemby opozycję, która - zgodnie z organizacją Kościoła katolickiego - nie ma prawa istnieć. Jedną z jego charakterystycznych cech jest bowiem według niej uznanie się za jedyną organizacyjną strukturę legitymizowaną mocą transcendencji. Autorka powołuje się na fragment wypowiedzi kardynała Josepha Ratzingera w rozmowie z Vittorio Messorim, opublikowanej w 1985 r.: dla katolików tylko fasada Kościoła jest ludzkim dziełem, poza nią istnieją struktury stworzone przez Boga, zatem niezachwiane i trwałe. Według Halemby chciał on tym samym przypomnieć, że hierarchia kościelna jest zgodna z wolą Bożą i że Bóg nie może być oddzielony od religijnej organizacji (Halemba 2015: 269).

Dialektykę między instytucjami i organizacjami laickimi a organizacją Kościoła Halemba uznaje w konsekwencji za pozorną. Chociaż katolicy praktykują na całym świecie różne formy życia religijnego, jednocześnie, poprzez identyfikację z Kościołem, poddają się według niej wpływowi organizacyjnych struktur charyzmatycznej biurokracji, które mają na celu ustanowienie granic tego, co dopuszczalne w życiu religijnym, włączając w to religijne eksperymenty. Wierni, jak przyznaje Halemba, mogą się nie zgadzać z poszczególnym decyzjami religijnych dostojników i kontestować ich orzeczenia, a niekiedy mają nawet do dyspozycji mocne środki, dzięki którym mogą negocjować z reprezentantami Kościoła. Mogą też korzystać z kapitału symbolicznego i innych typów źródeł, legitymizowanych przez organizację. Jednak praktyki religijne współczesnych ruchów katolickich, włączając obserwowane przez autorkę objawienia maryjne w Dżubliku, uważa ona za przykłady brikolażu (Thomas Luckmann), pick and mix religion (Malcolm Hamilton) i „duchowego supermarketu" (David Lyon). Katolicy poruszają się według niej w obrębie wspólnej koncepcyjnej ramy, w której „indywidualność" oraz „brak reguł organizacyjnych” kształtuje wprawdzie ważną część ich narracyjnej 
strategii samookreślenia, ale nie odzwierciedla rzeczywistości tych praktyk. Różnica między ruchami „bez organizacji” a tymi, które się określają jako przynależne do Kościoła, polega według niej na tym, że uczestnicy tych ostatnich, chociaż cenią wysoko „rozwój duchowy”, ,indywidualność" i „osobiste doświadczenie”, wybierają jako legalne źródło religię światową, scentralizowaną i hierarchiczną charyzmatyczną biurokrację. Poczucie, że jest się wierzącym katolikiem, jest konstytutywne dla wyborów dokonywanych w sferze osobistej praktyki religijnej. W tym znaczeniu Kościół staje się repozytorium symboli i praktyk wykorzystywanych w konstruowaniu duchowości, która wciąż jest rozumiana jako „osobista” i „budowana na doświadczeniu” ${ }^{4}$ - konstatuje Halemba.

W wyniku powyższych wniosków, dotyczących postaw duchownych rozmówców oraz praktyk wiernych, Halemba formułuje za Thimotym Byrnesem tezę, że Kościół katolicki, w którym „biurokracja może stanąć na straży charyzmy w owocnej relacji dialektycznej", zajmuje w polityce pozycję nieosiągalną dla żadnej innej religijnej organizacji. Może bowiem angażować się na wszystkich poziomach postkomunistycznej polityki: na poziomie globalnym za pośrednictwem roli i wpływów Stolicy Apostolskiej; na poziomie narodowym za pośrednictwem Konferencji Episkopatów; na poziomie indywidualnym za pośrednictwem działań papieża i wpływowych biskupów oraz przez wierne życie milionów katolików.

W kontekście dialektyki biurokracji i charyzmy Halemba dzieli katolickich księży na dwie grupy, odpowiadające postawom wobec dżublickich objawień. Pierwsza postrzega Kościół jako administratora i zarządcę charyzmy oraz jej nośnik (carrier), najwyższe dobro i ucieleśnienie świętości. Kościół to dla niej hierarchia, a niesubordynacja jest jednym z poważniejszych grzechów. Liczy się tylko to, czy rozwój nowego miejsca pielgrzymkowego ostatecznie wzmocni Kościół. Druga grupa postrzega charyzmęjako siłę niezależną od struktur kościelnych i uznaje, że należy za nią podążać za wszelką cenę - nawet Kościoła jako organizacji. Dla tych kapłanów najważniejszy jest Bóg i jego wola, a jeśli Kościół (jako organizacja) nie wydaje się za nią podążać, mogą się wobec niego zbuntować. Wówczas postacie transcendencji mogą być sprzymierzeńcami, mobilizowanymi aby rzucić wyzwanie organizacyjnym strukturom charyzmatycznej biurokracji, za których założycieli uznaje się właśnie owe moce. Według Halemby ta argumentacja często opiera się na rodzaju sylogizmu. W przypadku Dżublika wezwanie do jedności

\footnotetext{
${ }^{4}$ Cudzysłowy w tym akapicie pochodzą od autorki i wyrażają jej sceptycyzm wobec autodeklaracji katolików.
} 
Ukrainy może być podsumowane tak: to, o czym mówi Maryja,jest dobre; Maryja mówi o sprawach dotyczących jedności Ukrainy; zatem jedność Ukrainy jest dobra.

Jak dowodzi Halemba, trudna pozycja organizacji religijnej w konfrontacji z bezpośrednim doświadczeniem boskiej interwencji jest szczególnie niebezpieczna w post-sowieckim kontekście. Życie religijne w ZSRR nie zostało bowiem wyeliminowane, lecz głęboko przekształcone. Wśród stronników Kościoła greckokatolickiego, zakazanego i prześladowanego w większości krajów radzieckiego bloku, te przemiany były w dużej mierze związane z działalnością świeckich wierzących i podpolnych księży w sytuacji, w której struktury organizacyjne praktycznie przestały istnieć, zatem nie mogły nadzorować życia religijnego. Halemba konstatuje, że w przypadku zakarpackich grekokatolików, a w każdym razie tych, którzy przyjmowali podpolników do swoich domów lub prowadzili życie religijne w ogóle bez duchownych, organizacja religijna zmieniła się w odległy, choć ważny horyzont przynależności i odniesienia oraz wirtualne źródło legitymizacji. Wierni cenili Kościół jako ideę i jako ideał, uosobiony w postaci papieża i, bardziej lokalnie, w postaciach podziemnych księży-męczenników, często uznawanych za świętych cudotwórców oraz wzory pobożności, ale nie „funkcjonariuszy Kościoła i organizacji” (Halemba 2015: 274). Nie oczekiwali też od tej organizacji, aby miała jakikolwiek bezpośredni wpływ na lokalne praktyki i decyzje związane z instytucjami religijnymi.

Wydarzenia w Dżubliku Halemba uznaje za symptomatyczne dla zmiany życia religijnego na Zakarpaciu, kiedy wierni są wciąż przywiązani do Watykanu jako odległego punktu odniesienia, lecz rozluźniają się ich więzi ze społecznością lokalną. Zaczynają więc postrzegać życie religijne raczej jako poszukiwanie osobistego doświadczenia niż przywiązanie do lokalnych instytucji. Jednak organizacje religijne nie poddają się, a dostojnicy kościelni dokładają starań, aby odzyskać instytucje religijne i doświadczenia, które rozwijają się na zewnątrz lub na krawędziach granic ich organizacji(np. w zakonach) i objąć je „organizacyjnym uściskiem”. Miejsca objawień mogą być zatem postrzegane jako miejsca religijnych eksperymentów, na które Kościół katolicki przyzwala "w obrębie i na poboczach swoich organizacyjnych struktur".

Jak wspomniałam, Halemba podejmuje dyskusję z tezą Vlada Naumescu dotyczącą prawosławnego imaginarium Zachodniej Ukrainy jako wspólnoty praktyk religijnych prawosławnych i grekokatolików, umożliwiających im płynne przechodzenie między Kościołami. Autorka wskazuje postępy organizacji kościelnych jako przyczynę stopniowego tworzenia odseparowanych sieci wspólnot prawosławnych i katolickich. Kościoły 
prawosławne i katolicki dostarczają swoim zwolennikom odmienne zestawy religijnych technologii, co powoduje materialne manifestacje różnic między tymi wspólnotami. Chociaż większość hierarchów Kościoła greckokatolickiego na Zakarpaciu pobierała edukację w placówkach katolickich w tradycji łacińskiej, Halemba uważa, że proces różnicowania nie może być postrzegany jak niegdyś jako latynizacja, ponieważ Watykan opowiada się za re-bizantynizacją wschodniej gałęzi Kościoła. Jednak ta polityka nie przybliża praktyk religijnych czy „materialności” grekokatolików do lokalnych prawosławnych wspólnot, bo inspiracje czerpie z Grecji, a nie z lokalnych Kościołów prawosławnych. Paradoksalnie jest też symptomem zachodniego sposobu myślenia, bo przez zachętę do powrotu do "prawdziwej wschodniej tradycji” Watykan promuje jej jednolitość, co jest sprzeczne z modelem wschodniego chrześcijaństwa jako zgromadzenia kościołów głęboko osadzonych w lokalności. Skoro Kościół greckokatolicki jest częścią globalnego, scentralizowanego Kościoła katolickiego, to argumenty upowszechniające rozumienie sytuacji Kościoła greckokatolickiego jako przynależnego do wschodniego chrześcijaństwa powinny według autorki budzić nieufność.

Zanim przejdę do uwag krytycznych, podsumuję realizację projektu monografii. Autorka prowadzi czytelnika poprzez swoją klarowną narrację niejako za rękę, tak że nie sposób się w tekście pogubić, pomimo wielowątkowości narracji i bogactwa materiału. Można się od niej uczyć konsekwencji racjonalnego i przejrzystego konstruowania narracji. Co prawda czasami też odnosi się wrażenie zbyt częstych powtórzeń, jakby chodziło o wbicie czytelnikowi do głowy nie tyle informacji, co tez sformułowanych przez autorkę. Polityczny obraz Zakarpacia został przedstawiony w sposób szczegółowy i przekonujący. Do etnograficznej strony oraz struktury pracy Agnieszki Halemby trudno mieć zastrzeżenia. Gęste opisy konstruuje profesjonalnie, ze znakomitym wyczuciem szczegółu, wieloaspektowo. Rozmówców traktuje dyskretnie i z sympatią, a ich wypowiedzi cytuje z zachowaniem oryginalnych idiomów i omówieniem ich specyficznego, kontekstowego znaczenia. Diagnozę problemów w relacjach między Kościołem jako organizacją na poziomie eparchii mukaczewskiej a lokalną wspólnotą religijną Zakarpacia, funkcjonującą w ramach postradzieckiego ukraińskiego prawa, przedstawiła wnikliwie i wieloaspektowo. Na tym poziomie narracji skonstruowany na początku model okazał się efektywny. Bogatemu obrazowi życia religijnego trudno cokolwiek zarzucić; wzbudza szacunek wobec zmysłu obserwacji autorki.

Moje wątpliwości budzi natomiast rozszerzenie wniosków z zakarpackich badań na Kościół katolicki oraz ich redukcyjny charakter, ograniczany stopniowo do 
organizacyjnego aspektu religii. I tak np. uważam za przesadne stwierdzenie, że „poprzez otwartą deklarację, że jest bez znaczenia, czy chrześcijanin wierzy w prywatne objawienia maryjne, czy je odrzuca, Kościół przekształca je w nie-zdarzenia (non-events), czyli epizody pozbawione konsekwencji" (Halemba 2015: 278).

Już we wstępie, po prezentacji trójaspektowego modelu, autorka wyznaje, że interesuje ją przede wszystkim interakcja pomiędzy religijnymi instytucjami a „organizacyjnym włączaniem”, w mniejszym zaś stopniu doświadczenia (Halemba 2015: 5). Uważam, że we wnioskach zmarginalizowany został również w odniesieniu do Kościoła aspekt instytucjonalny, co radykalnie zawęża perspektywę badawczą i tworzy pułapkę samopotwierdzania się założonych od początku elementów teoretycznych oraz, powiedzmy to, ideologicznych. Zakończenie w pewnym stopniu nawet unieważnia bogactwo etnograficznego opisu, kiedy Autorka konstatuje, że współczesny Kościół katolicki:

próbuje przekonać ludzi, że ich wierzenia i doświadczenia nie mają żadnych następstw. Pęknięcie zostaje zmyte z obrazu - objawienie może być ocenione jako autentyczne wyłącznie wówczas, jeśli wszystko pozostanie takie samo.

Kościół katolicki zupełnie nie jest zainteresowany prawdziwością objawień. To tak jakby Kościół twierdził, że, chociaż ktoś może myśleć, że ma kluczowe znaczenie, czy Maryja się objawiła, nie ma to żadnego znaczenia. To co rzeczywiście ważne dla Kościoła, to ciągłość kontroli organizacyjnej wobec religijnych doświadczeń i instytucji (Halemba 2015: 278).

Skoro autorka postrzega Kościół katolicki przede wszystkim jako scentralizowaną i zbiurokratyzowaną globalną organizację polityczną, co więcej, interesuje ją głównie ten właśnie jego globalny wymiar, to otrzymuje efekt, który wypracowała: Kościół - jak każda organizacja - musi być zainteresowany „kontynuacją organizacyjnej kontroli religijnych doświadczeń i instytucji”, która z tej ograniczonej perspektywy jest jego głównym celem. I oczywiście tak jest, tylko że nie tłumaczy to w żaden sposób jego statusu w porównaniu z innymi organizacjami, które stawiają sobie dokładnie ten sam główny cel. W świetle końcowych wniosków odnosi się wrażenie, że autorka rozdzieliła antagonistyczne role i traktuje Kościół katolicki wyłącznie jako organizację, a laikat jako wytwarzający instytucje, odpowiednio reinterpretowane i zawłaszczane przez Kościół. Uważam za przesadzony taki dualistyczny podział Kościoła, który od czasu Vaticanum II mocno akcentuje swój charakter wspólnotowy, łączący laikat i duchownych, i podkreśla znaczenie sensus fidei. 
To dla samej autorki, przyjmującej odesencjalizowaną perspektywę nauk społecznych, indywidualne objawienie (czyli „specjalna rzecz”) jako takie nie ma znaczenia poza tym, że „jest narzędziem negocjacji i transformacji w obszarze religijnym”, a wreszcie - że mogłoby tego doświadczenia w ogóle nie być (Halemba 2015: 279). To według interpretacji autorki „nie ma przyczynowego związku między doświadczeniem wizjonera a tym, co następnie się dzieje na miejscu objawienia" (Halemba 2015: 84). Uważam, że nie jest to wniosek, a założenie wynikające z podejścia kognitywistycznego, które sugeruje, że „na czysto osobistym poziomie doświadczenie nigdy nie jest religijne. To społeczne instytucje i organizacje tworzą dziedzinę / pole religii" (Halemba 2015: 279). Jest to zaiste teza Durkheimowska. A jeśli ktoś zinternalizował owe społeczne, instytucjonalne znaczenia, które formują jego ekspresję i umożliwiają mu twórcze konstruowanie tożsamości? Jeśli potrafi wykorzystać kapitał symboliczny Kościoła w sposób, który prezentuje Michel de Certeau (2008: 26-29) jako przechwytywanie, akt wymiany - wywrotowego perukarzu, co udało się w Kościele katolickim np. siostrze Faustynie Kowalskiej?

Zapewne właśnie ze względu na brak zainteresowania autorki samym objawieniem nie otrzymujemy opisu ikonografii jego przedstawień, a obraz umieszczony w Dżubliku, w miejscu tego wydarzenia, nie został czytelnikowi udostępniony, chociaż dowiadujemy się, że jego kopie są obecne w domach wiernych (Halemba 2015: 227). Nie dowiadujemy się również, jakie przedstawienia znalazły się w głównym ołtarzu sanktuarium. Halemba wspomina, że w domach dżublikowskich widziała nowe obrazy dewocyjne o niespotykanej w regionie estetyce. Jednak na załączonej fotografii, która ma to potwierdzać, widnieje Chrystus umęczony (w języku ikonografii zachodniej zwany Vir Dolorum, Mężem Boleści, w języku ikonografii wschodniej cs. Carem Sławy, Królem Chwały). Jest to przedstawienie, które wywodzi się z Bizancjum i dość powszechnie występuje na naczyniach liturgicznych. Trudno sobie wyobrazić, aby stanowiło nowość na terenach Zakarpacia, gdzie krzyżują się obie tradycje ikonograficzne.

Za pomyłkę, wywołaną przesadną koncentracją na organizacyjnym aspekcie funkcjonowania Kościoła, uważam również czasową lokalizację odrodzenia religijnego. Halemba dowodzi, że:

tak zwane „odrodzenie religijne" po upadku ZSRR nie dotyczyło głównie odrodzenia wiary, rozumianej jako postawa umysłu (as a mental state), a nawet nie odrodzenia określonych praktyk religijnych, które, jak przekonująco pokazała Dragadze, często 
bywały „udomowione”, lecz odrodzenia publicznej obecności religijnych organizacji, które w ZSRR wypuściły życie religijne ze swego uścisku, a obecnie pracują nad odzyskaniem kontroli (Halemba 2015: 178).

Zgodziłabym się prawie ze wszystkim w tym zdaniu; o wierze domowej polskiej wsi na Litwie pisałam w 1991 r., chociaż w przeciwieństwie do autorki uważam, że na badanych terenach „religia udomowiona”, wspomagana przez dziadów wędrownych, konkurowała z religią kościelną jeszcze przed eliminacją organizacji religijnych w czasach ZSRR. Jednak odrodzenie religijne, zarówno w przypadku prawosławia, jak i katolicyzmu, miało miejsce przed, a nie po upadku ZSRR, o czym świadczą głosy świadków, którzy wiązali je z jubileuszem 1000-lecia chrztu Rusi obchodzonego w 1988 r., a także z działalnością kilku wybitnych postaci Cerkwi prawosławnej, jak ojciec Aleksander Mień. To właśnie z okazji jubileuszu władze radzieckie po raz pierwszy rozluźniły nieco wobec wiernych uścisk jedynej organizacji, która mogła tam wówczas faktycznie swobodnie funkcjonować, czyli KPZR. Również na Ukrainie aktywność laikatu, której symptomem może być walka o odzyskiwanie budynków kościelnych oraz budowa nowych świątyń, znacząco wyprzedziła uzyskanie niepodległości. Było to organizowanie się oddolne, pośrednio tylko związane z „globalną biurokratyczną organizacją Kościoła katolickiego”.

Uważam również za przesadną konstatację, jakoby studia nad religią prowadzone w ZSRR nie dawały nam wyobrażenia o tym, jak wyglądało życie religijne praktykowane przez konkretnych ludzi, często pod nieobecność religijnych organizacji (Halemba 2015: 26). Może i nie było takich studiów przed upadkiem ZSRR, ale istnieje dość obfita rosyjska, ukraińska i polska literatura wspomnieniowa tego okresu, opublikowana w latach 90. i dotycząca różnych środowisk (np. wspomnienia księży katolickich, którzy jawnie bądź potajemnie pełnili posługę duszpasterską w czasach ZSRR, w tym na Ukrainie ${ }^{5}$ ). Dostępne są też w końcu liczne publikacje prezentujące materiały $z$ badań etnograficznych kultury religijnej podjętych tuż po upadku ZSRR, które dają jakieś wyobrażenie o wcześniejszym życiu religijnym. Autorka całkowicie je pomija, a przyjęte przez nią założenia oraz sposób interpretacji materiałów etnograficznych odwołują się głównie do współczesnej literatury zachodniej, często dotyczącej zupełnie innych środowisk życia religijnego w Europie Zachodniej czy Kanadzie. Wybór ten powoduje według mnie pewne braki, wyni-

\footnotetext{
${ }^{5}$ Np. rozmowy-rzeki Jana Pałygi SAC z Romanem Dzwonkowskim SAC czy z ks. Józefem Świdnickim.
} 
kające z niedostatków materiału porównawczego z kontekstu post-radzieckiego czy ukraińskiego. Początkowy holistyczny projekt antropologii chrześcijaństwa przekształca się na koniec $\mathrm{w}$ antropologię organizacji, skoncentrowaną - jak to formułuje autorka - na "antropologicznych badaniach nad zarządzaniem objawieniami i cudami” (Halemba 2015: 2) i to tylko przez Kościół katolicki.

Autorka pisze o objawieniach maryjnych jako specjalności katolickiej(Halemba 2015: 62, 90). Nie do końca jest to prawda; w każdym razie nie w przypadku Ukrainy $^{6}$. Trochę szkoda, że publikacje ukraińskich badaczy na ten temat nie zostały w pracy uwzględnione. Przyjmuję także z pokorą brak jakiegokolwiek odniesienia do dość licznych publikacji moich kolegów i moich własnych dotyczących kultury religijnej w różnych częściach Ukrainy, a także w innych krajach postsocjalistycznych. Wprawdzie rzadko dotyczą one organizacji życia religijnego, niekiedy jednak uwzględniają interesujące autorkę problemy, jak ukraińska recepcja lokalnej wersji Radia Maryja, różne formy konfrontacji religijnych nowinek z tradycją czy sposoby funkcjonowania tzw. małżeństw mieszanych, katolicko-prawosławnych.

Chociaż ogólnie zgadzam się z komentarzem autorki, podważającym tezę Vlada Naumescu o wspólnocie „prawosławnego imaginarium” prawosławnych i grekokatolików wobec aktualnego stanu rzeczy (różnicuje się ono pod w pływem organizacji kościelnych), muszę zaprotestować w kwestii prezentowanego przez nią stanowiska co do rzekomych różnic w stylach i ikonografii przedstawień dewocyjnych. Z moich obserwacji wynika, że świadomość tych różnic zazwyczaj nie jest udziałem wiernych, a często nawet i duchowni się w nich nie orientują; jeśli już, to raczej duchowni prawosławni, którzy tępią łacińskie elementy wystroju cerkwi jako niekanoniczne. Dotyczy to także kwestii odmienności stylów figur w kapliczkach katolików i prawosławnych oraz różnic w ich architekturze. Są to, w moim odczuciu ${ }^{7}$, konstrukcje hybrydowe, czy, jeśli ktoś woli, ekumeniczne. Np. rozpoznanie przez Halembę (2015: 244) figury maryjnej w kapliczce grekokatolików w Silce jako wyraźnie nawiązującej do przedstawień z Lourdes jest mylące. Jest to Orantka, przypominająca Pokrow (Opiekę Matki Bożej), a zatem typ rozpowszechniony w prawosławiu, w przeciwieństwie

\footnotetext{
${ }^{6}$ Mam tu na myśli m.in. słynne objawienie Matki Bożej pastuszkom na Jozafatowej Dolinie, zwanej też Doliną Krzyży, koło wioski Hołynczyncy na Podolu (obwód winnicki), które miało miejsce w 1923 r. (czyli w 45 lat po Lourdes). To jeden z dwóch przypadków cudów, prezentowany w pracy etnologa Wolodymyra Djakiwa (2008). Drugim był krwawiący krzyż w wiosce Kaliniwka, co również mogło by być interesujące dla porównania z krwawiącym krzyżem Dżublika.

${ }^{7}$ Nie prowadziłam badań na Zakarpaciu, więc odnoszę się tylko do zamieszczonych w monografii fotografii i komentarza autorki.
} 
do Niepokalanego Poczęcia (dogmat w Kościele katolickim), prezentowanego przez objawienie w Lourdes. Figura wydaje się łączyć oba typy.

Ale celem pracy jest nie tyle analiza fenomenu Dżublika w kontekście ukraińskim, co raczej globalnym, co w dużym stopniu tłumaczy wybór literatury i egzotycznych porównań. Wiąże się to również z zagubieniem we wnioskach głównego protagonisty Kościoła katolickiego, czyli Ukraińskiego Kościoła Prawosławnego Patriarchatu Moskiewskiego, nadal gromadzącego na Zakarpaciu najliczniejszą grupę wiernych. Chociaż badania obejmowały prawosławnych, „organizacyjne włączanie" prezentowane jest na przykładzie demonizowanego Kościoła katolickiego, bez uwzględnienia jego interakcji z silniejszą konkurencją.

Spójny, nowatorski projekt badawczy oraz jego znakomita realizacja przynoszą zatem wnioski, z których kilka uważam za dyskusyjne. Moje uwagi krytyczne dotyczą głównie wynikającego z założeń teoretycznych pomijania przez Agnieszkę Halembę pewnych szczegółów czy aspektów badanych zjawisk. Wiążą się one również w pewnym stopniu z odmiennością przyjętej przeze mnie perspektywy w badaniach kultury religijnej oraz z moimi doświadczeniami badawczymi z innych regionów Ukrainy. W wielu przypadkach nasze obserwacje i wnioski pozostają jednak zbieżne. Bardzo sobie cenię tę monografię, świadczącą o zróżnicowaniu kultury religijnej Ukrainy oraz o tym, jak wiele zależy od wyboru czynników, jakie bierze się pod uwagę w badaniach porównawczych. Jest to książka oryginalna i inspirująca, zarówno ze względu na program teoretyczny, jak i sugestywne, pogłębione studium kultury religijnej Zakarpacia.

\section{Bibliografia}

Certeau de, M. (2008). „La perruque” - praktyka przechwytywania. W: Tenże. Wynaleźć codzienność. Sztuki działania (przeł. K. Thiel-Jańczuk), ss. 26-29. Kraków: WUJ.

Djakiw, W. (2008). „Folklor czudes” u pidradjanskij Ukrajini 1920-ch rokiw. Lwów: Nacional'na Akademija Nauk Ukrajiny, Instytut Narodoznawstwa.

Halemba, A. (2014). Objawienia i duchy gór - doświadczenia, instytucje i organizacje religijne, Zeszyty Naukowe Uniwersytetu Jagiellońskiego. Prace Etnograficzne , 42 (1), 33-46.

Halemba, A. (2015). Negotiating Marian Apparitions. The Politics of Religion in Transcarpathian Ukraine. Budapest-New York: CEU PRESS. 
Lévi-Strauss, C. (1993). Etnolog wobec kondycji ludzkiej (przeł. W. Grajewski). W: C LéviStrauss. Spojrzenie z oddali, ss. 55-72. Warszawa: PIW.

Piwowarski, W. (red.). (1996). Socjologia religii. Lublin: Wydawnictwo KUL.

Taves, A. (2009). Religious Experience Reconsidered: A Building Block Approach to the Study of Religion and Other Special Things. Princeton: Princeton University Press. 